\title{
Urban Transport Sustainability Indicators - Application of Multi-view Black-box (MVBB) framework
}

Hippu Salk Kristle Nathan and B. Sudhakara Reddy

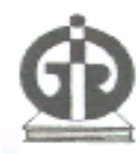

Indira Gandhi Institute of Development Research, Mumbai September 2011 http://www.igidr.ac.in/pdf/publication/WP-2011-022.pdf 


\title{
Urban Transport Sustainability Indicators - Application of Multi-view Black-box (MVBB) framework
}

\author{
Hippu Salk Kristle Nathan and B. Sudhakara Reddy \\ Indira Gandhi Institute of Development Research (IGIDR) \\ General Arun Kumar Vaidya Marg \\ Goregaon (E), Mumbai- 400065, INDIA \\ Email (corresponding author): 는.in
}

\begin{abstract}
In a recent work Nathan and Reddy (2011a) have proposed a Multi-view Black-box (MVBB) framework for development of sustainable development indicators (SDIs) for an urban setup. The framework is flexible to be applied to any domain or sector of urban system. In this paper the proposed MVBB framework is applied for transportation sector of Mumbai city. The paper begins with a discussion on transportation sector and its unsustainability links and trends. It outlines the concept of sustainable transportation system and reviews some of the prominent sustainable transportation indicator initiatives. In order to formalize sustainable development indicators (SDIs) for transportation sector, the study collates the indicators from literature, placed them in Mumbai's context and classified them into the three dimensions of urban sustainability-economic efficiency, social wellbeing and ecological acceptability.
\end{abstract}

Keywords:

Sustainable transportation system, Potential indicators, Urban sustainability, MVBB, Transport indicators, Economic efficiency, Social wellbeing, Ecological acceptability

JEL Code:

O18, Q01, L92

Acknowledgements: 


\title{
Urban Transport Sustainability Indicators \\ - Application of Multi-view Black-box (MVBB) framework
}

\author{
Hippu Salk Kristle Nathan and B. Sudhakara Reddy
}

\begin{abstract}
$\underline{\text { Abstract }}$
In a recent work Nathan and Reddy (2011a) have proposed a Multi-view Black-box (MVBB) framework for development of sustainable development indicators (SDIs) for an urban setup. The framework is flexible to be applied to any domain or sector of urban system. In this paper the proposed MVBB framework is applied for transportation sector of Mumbai city. The paper begins with a discussion on transportation sector and its unsustainability links and trends. It outlines the concept of sustainable transportation system and reviews some of the prominent sustainable transportation indicator initiatives. In order to formalize sustainable development indicators (SDIs) for transportation sector, the study collates the indicators from literature, placed them in Mumbai's context and classified them into the three dimensions of urban sustainability-economic efficiency, social wellbeing and ecological acceptability.
\end{abstract}

JEL Codes: O18, Q01, L92

Keywords: Sustainable transportation system, Potential indicators, Urban sustainability, MVBB, Transport indicators, Economic efficiency, Social wellbeing, Ecological acceptability. 


\section{Introduction}

Transportation system forms the veins and arteries of the anatomy of urban life. It is responsible for the physical movement of people and goods. A well-functioning transport system is central to the development of a society. Transport gives access to resources and markets, health, education, and other amenities. However, inappropriately designed transport strategies and programs, can result in networks and services that ignore the changing needs of users, aggravate the condition of the poor, harm the environment, and exceed the capacity of public finances (World Bank, 1996). In urban areas, where intense transportation activities are associated with high spatial concentrations of people and activities, these socio-economicenvironmental impacts are more pronounced (Loo and Chow, 2006). Transport sector is considered as one of the most significant sources of unsustainability in urban areas (May et al., 2003).

Transportation is both energy- and emission-intensive as it uses considerable quantities of fossil fuels, particularly oil and contributes substantially to greenhouse gas emissions (Price et al., 1998, Åkerman and Höjer, 2006). The world consumes more oil than any other primary energy, ${ }^{1}$ and transportation accounts for more than half of the total primary oil demand (IEA, 2008). It also accounts for $23 \%$ of total $\mathrm{CO}_{2}$ emissions, of which $73 \%$ is generated by road transport (IEA, 2007a). The rate of growth of transport sector energy demand was $2.3 \%$ in 1980-2006, and its share in the total global final energy consumption has increased from 23 to $28 \%$ during the same time period.

Because of the limited substitution (mainly in road transport) and short-run price inelasticity for oil in transportation (Dahl, 1994; Krichene, 2002), the sector will account for threequarters of the projected increase in oil demand worldwide; and its share in global primary oil consumption in 2030 will be 57\%, compared with 52\% in 2006 and 38\% in 1980 (IEA, 2008). Out of the total world transportation oil demand in 2005-2030, developing countries will have a three-fourths share on account of faster growth in economies and populations compared to their developed counterparts (IEA, 2007b). ${ }^{2}$ Urbanization and rising income levels have instrumented rapid increase in present and future transportation demand and

\footnotetext{
${ }^{1}$ The share of oil in total primary energy demand is $34 \%$, followed by coal, natural gas and biomass, whose shares are 26,21 and $10 \%$ respectively.

${ }^{2}$ Developing countries will account for about three-fourths of the overall energy use and four-fifths of the overall oil demands during 2005-2030.
} 
vehicle ownership and use in developing countries (Faiz and Sturm, 2002). This has posed a serious challenge to energy security and sustainability of different societies and to the world as a whole.

With regard to the future of transportation, the importance of urban areas of developing countries cannot be over emphasized. As Global urban observatory (2003) notes that 95 per cent of the buildup of humanity during 2000-2030 will occur in the urban areas of developing countries, and by 2015, out of the 26 mega cities of the world, 22 will be in developing countries (UNFPA, 1999). Because of the rapid growth of cities in the developing world, IEA (2008) acknowledges that the pattern of energy use in cities of developing world will increasingly shape the global energy use. There is a broad agreement in the literature about unsustainability of world transportation (Greene and Wegener, 1997; Banister, 1999; Hall and Pfeiffer, 2000), and cities in developing countries face more severe symptoms of unsustainable transportation such as traffic congestion and accidents (fatalities and injuries), deteriorating environmental safety and security (Gakenheimer, 1999; Vasconcellos, 2001; Gwilliam, 2003; Pucher et al., 2005).

In this paper, we attempt to develop urban sustainability indicators for transportation sector of an urban setup. ${ }^{3}$ For this purpose, the most populous city of India, i.e., Mumbai has been chosen. This paper executes the initial step of ascertaining the potential list of SDIs for transportation sector of Mumbai. First, the concept of sustainable transport system is outlined. Mumbai's state of urbanization and transportation is briefed next. Then, different SDI initiatives in literature, both specific to and inclusive of transportation are reviewed. Further, the multi-view black-box (MVBB) framework, developed by Nathan and Reddy (2011a) has been applied to the transportation sector to contextualize and classify the indicators in the three dimensions-economic efficiency, social wellbeing and ecological acceptability. Finally, the potential list of indicators are presented with their definition, expression and meaning. ${ }^{4}$

\footnotetext{
${ }^{3}$ This paper is the third paper in the series. The first study (Nathan and Reddy, 2011a) established the conceptual framework to develop SDIs to assess sustainability of resource use in an urban setup. The second study (Nathan and Reddy, 2011b) builds the criteria selection framework and methodology to arrive at final set of indicators from a potential list.

${ }^{4}$ By listing the potential indicators, this paper prepares the foundation on which the selection framework and methodology established in Nathan and Reddy (2011) can be applied to ascertain the final set of SDIs for Mumbai’s transportation sector.
} 


\section{Sustainable Transportation System}

The concept of sustainable transportation system is based on the notion of sustainable development, ${ }^{5}$ and there is a multitude of definitions. ${ }^{6}$ As per one definition, a 'sustainable transportation system' is defined as the one in which fuel consumption, vehicle emissions, safety, congestion, and social and economic access are of such levels that they can be sustained into the indefinite future without causing great or irreparable harm to future generations of people throughout the world (Richardson, 1999). By another definition, sustainable transportation attempts to address economic development, environmental stewardship, and social equity of current and future generations (Zietsman and Rilett, 2001). Richardson (2005) notes, irrespective of specific definition of sustainable transportation, there is consensus on "triple bottom line" of economic, social and environmental sustainability. ${ }^{7}$ These three dimensions of transportation sustainability as conceptualized by World Bank (1996) are as follows. Economic sustainability of transportation ensures continuing capability to support the transportation demand with cost-effective and competitive solutions. Social sustainability addresses the transportation needs of poor and confirms equitable sharing of benefits of transportation by all sections of society. Environmental sustainability relates to transportation which reduces the negative impacts on environment and thereby generates the greatest possible improvement in the general quality of life. This concept of transport sustainability confirms well with the three components of urban sustainability-economic efficiency (EE), social wellbeing (SW) and ecological acceptability_of multi-view black-box (MVBB) framework as conceived in Nathan and Reddy (2011a). ${ }^{8}$ The three dimensions are elaborated further.

Economic dimension in transportation looks into the productivity of its resource use, its contribution to the economy and satisfaction of economic needs of people. Also, from economic point of view, transportation sector not only facilitates business, but it is a business

\footnotetext{
${ }^{5}$ The most widely accepted definition of sustainable development as put forwarded by Brundtland Commission report of 1987 - that introduced inter- and intra-generation equity - is 'the development which meets the needs of the present without endangering the ability of future generation to meet their own needs' (WECD, 1987). For a brief discussion on notion of sustainable development, see Nathan and Reddy (2011a).

${ }^{6}$ For definition, meaning and scope of sustainable transport system see Gordon (1995), O’Rourke and Lawrence (1995), Black (1996), Duleep (1997), Transportation Research Board (1997), Richardson (1999, 2000), Zietsman and Rilett (2001) among others.

7 This triple bottom line definition of transport sustainability is conceptualized by World Bank (1996) and adopted by TAC (1999), Loo (2002), Schipper (2003), Schiller et al. (2010) among others.

8 The multiple views in MVBB framework are nothing but economic efficiency view (EE-view), social wellbeing view (SW-view), and ecological acceptability view (EA-view).
} 
by itself. Transportation needs to be cost-effective to be financially sustainable. Acknowledging the importance of economic dimension of transportation, World Bank (1996) suggests that economic sustainability requires sustainability in vehicle fleet, transportation infrastructure and public transportation system. Transport services-as agents of change-not only contribute to the economy through production of vehicles, production of fuels that power the vehicles and provision of transport infrastructure, but also 'creates' raw material and labor, which is otherwise unusable due to its inaccessibility, and 'combine' (unite) them by broadening the areas of the business activity (WBCSD, 2004). ${ }^{9}$ Literature concerned with developing world has shown that though transportation is not a panacea to poverty, it has enhanced the agricultural outputs and access to market and essential services (Binswanger et al., 1993; Jacoby, 1998).

Transportation sector is governed by social changes (Black and Nijkamp, 2002). Also, transportation planning has consequences on social dimensions like equity and exclusion (Ahmed et al., 2008, Kenyon et al, 2002). The prioritization of highway development over public transportation has had inequitable effects on low-income populations, often restricting their ability to access social and economic opportunities, including job opportunities, education, health care services (Sa'nchez et al., 2003). Relative emphasis on people who are already motor-mobile as against the ones who are walking or unconnected with the existing transportation network would increase the rich poor gap in the society. Also poor in the cities tend to spend more on transportation (Laquian, 2004). In the cities of many developing countries, poor families sometimes spend up to $20 \%$ of their income on transport, while the average family does not even require half that sum for its mobility needs (GTZ, 2002). Safety of human life has also become a major concern in transportation. As per World Health Organization (WHO) Global Burden Disease study (Murray and Lopez, 1996; WHO, 2002), road traffic injuries in developing countries are the cause for one fourth of injury-related deaths. It is ranked ninth in the overall cause of death in 1990, which is likely to rise to the sixth rank by 2020, with India, in particular, bearing the most of the burden.

Environment dimension of transportation is concerned with renewability of resource use and cleaner environment for current and future generation. Transportation contributes

\footnotetext{
${ }^{9}$ This has been evidenced in a study (Baum and Kurte 2002) in Germany, where the authors concluded that transportation was "responsible" for nearly half the growth that occurred in Germany post-World War II, i.e., during 1950-1990.
} 
significantly to environment pollution. Globally, transport sector produces $14 \%$ of GHG emissions (Hensher, 2008). Loo (2002) has noted that as per World Health Organization (WHO), in 1999, vehicles are responsible for as much as 90-95\% of CO and lead, and 60$70 \%$ of nitrogen oxide and hydrocarbon emissions from anthropogenic sources in city centers. Traffic noise, a nuisance of transportation, has also been considered as one of the major factors in decreasing the quality of ambience (WHO, 2000; Poudenx, 2008). The environmental impact of transportation must be checked, as the same, if left unchecked, can become so great that they inhibit transport systems from performing their central and minimal economic and social roles (WBCSD, 2004).

The sustainability analysis looks into both the positive and negative aspects of the transportation system (Richardson, 2005). ${ }^{10}$ Sustainable transportation system strategizes a compromise between these positives (benefits associated with transportation) and negatives (i.e., negative externalities of transportation) over the short to long term (World Bank, 1996). Sustainable transport planning requires integration of environmental, social, and economic factors in order to develop optimal solutions to many pressing issues, especially energy security, emissions, and climate change (Schiller et al., 2010). Sustainable transportation is faced with multitude of challenges (Lindquist, 1998; Zietsman, 2000). However, once clearly defined, quantified and used in the decision-making process, sustainable transportation can potentially address economic development, environmental stewardship, and social equity of current and future generations (Zietsman and Rilett, 2001). A high priority needs to be placed on sustainability issues of urban transportation, because it represents the largest and the greatest environmental and social opportunity to improving community quality of life (May et al., 2003; Holden and Norland, 2005). Transportation system is complex, and this complexity derives from the pluralism of its hardware (infrastructure and vehicles - with various mode types) and of the people and organizations involved. Each of the stakeholders in the transportation system-local, state, and federal governments; the fuel and motorvehicle industries; and public-transportation providers, users, and others-will have roles to play in moving towards sustainability (Richardson, 2000; 2005).

\footnotetext{
10 The positives associated with transportation are mobility, comfort, saving in terms of time, increase in productivity, enhancing equity and contributing to economy through transportation sector. The negative externalities can be air pollution, noise pollution, accidents, congestion, consumption of land, loss of habitat, waste disposal problem etc.
} 


\section{Sustainable Transportation Indic ator Initiatives}

There is overwhelming literature which advocates identifying and quantifying performance measures for the transportation system (Zietsman and Rilett, 2001; OECD, 2002; Litman, 2011). There have been instances of uses of multi dimensional measurement indicators in sustainability evaluation of transportation system. ${ }^{11}$ Likewise other domains and sectors, in sustainability study of transportation sector, developed economies lead the rest. Though there has been a greater agreement about the three dimensions (economic, social and political) of sustainability, there is no consensus on the actual indicators which represent each of these dimensions (Jeon and Amekudzi, 2005). ${ }^{12}$

In the pursuit of search for sustainable development indicator initiatives in transportation, the study has considered both the SDI initiates where transportation formed a significant component and the important SDI initiatives exclusive to the transportation sector. In entirety, 21 initiates are reviewed of which 10 are holistic SDI initiatives with transportation sector as a constituent and 11 are exclusive initiatives to assess the sustainability of transportation sector (Table 5.1). ${ }^{13}$ The scope for about half of the initiatives reviewed, i.e., 11 out of 21 pertain to sustainability of urban areas, whereas eight are country level studies, one each is provincial and transnational. ${ }^{14}$ Table 5.1 gives the scope and coverage of the initiatives. ${ }^{15}$ The dominance of developed economies in indicator initiatives is evident from the reviewed list. Out of the 21 initiations, two-thirds, i.e., 14 are from the developed worldsix from Europe, five from North America, and two from Australia and one from Asia, i.e., from Japanese city, Kitakyushu (Dhakal, 2002). The three developing country initiatives are from India (CSTI, 2007), China (Hualin, 2001) and South Africa (Cape Town, 2006). Four initiatives, namely, UNCSD (1996), WBCSD Mobility Indicators (Eads, 2001), OECD (2000c), UNCHS (2004), are of global or transcontinental. These initiatives are reviewed in

\footnotetext{
${ }^{11}$ For SDI initiatives in transportation see, Jeon and Amekudzi (2005) and Jeon et al. (2007), among others.

${ }^{12}$ Four of the 11 transportation specific initiatives covered in the present literature review have upfront grouped the indicators under social, economic and environment dimensions.

${ }^{13}$ The exclusiveness of the initiatives to transportation has been mentioned in the third column of Table 5.1.

14 Though the current study aims at developing SDIs for transportation for a city, initiatives with provincial, national and regional scope are included because the indicators which are important from country or regional perspective might as well turn relevant for a city.

${ }^{15}$ Here 'scope' and 'coverage' have different connotations. For a particular initiative scope and coverage can be different. For instance, the initiatives - quality of life study of London (2004), indicator program in China (Hualin, 2001), EU Local Sustainability Initiative (EC, 2001) and urban indicator program by UNCHS (2004) though urban in scope, the coverage is city-based, national, continental and global respectively.
} 
order to collate indicators related to transportation, which have relevance in Mumbai's context. ${ }^{16}$ Before returning to indicators, it is worthwhile to review briefly the transportation situation in India in general and Mumbai in particular.

Table 1 Summary of transportation indicator initiatives reviewed

\begin{tabular}{|c|c|c|c|c|}
\hline Initiative & Scope* & $\begin{array}{l}\text { Whether } \\
\text { exclusive to } \\
\text { transportation }\end{array}$ & $\begin{array}{l}\text { Transportation } \\
\text { dimension (s) } \\
\text { touched upon }\end{array}$ & $\begin{array}{l}\text { Classification of } \\
\text { indicators }\end{array}$ \\
\hline UNCSD (1996) & $\begin{array}{l}\text { Country } \\
\text { (global) }\end{array}$ & $\begin{array}{l}\text { No; under } \\
\text { 'sustainable } \\
\text { development' }\end{array}$ & $\begin{array}{l}\text { Economic and } \\
\text { environmental }\end{array}$ & $\begin{array}{l}\text { Four pillars: } \\
\text { social, economic, } \\
\text { environmental and } \\
\text { institutional }\end{array}$ \\
\hline $\begin{array}{l}\text { USA (USEPA, } \\
\text { 1996; USDOT, } \\
\text { 2003) }\end{array}$ & Country & $\begin{array}{l}\text { Yes; under transport- } \\
\text { environment } \\
\text { sustainability and } \\
\text { DOT’s performance }\end{array}$ & $\begin{array}{l}\text { Social, economic } \\
\text { and environmental }\end{array}$ & $\begin{array}{l}\text { As per different } \\
\text { modes of } \\
\text { transportation }\end{array}$ \\
\hline Australia (1998) & Country & $\begin{array}{l}\text { No; under 'human } \\
\text { settlement } \\
\text { sustainability' }\end{array}$ & $\begin{array}{l}\text { Social, economic } \\
\text { and environmental }\end{array}$ & $\begin{array}{l}\text { System } \\
\text { framework } \\
\text { classification }^{+}\end{array}$ \\
\hline Bologna (2000) & City & $\begin{array}{l}\text { No; under 'state of } \\
\text { the environment' }\end{array}$ & $\begin{array}{l}\text { Social, economic } \\
\text { and environmental }\end{array}$ & $\begin{array}{l}\text { As per different } \\
\text { resources }\end{array}$ \\
\hline OECD (2000c) & $\begin{array}{l}\text { Country } \\
\text { (regional) }\end{array}$ & $\begin{array}{l}\text { Yes; under } \\
\text { 'transport- } \\
\text { environment } \\
\text { sustainability' }\end{array}$ & $\begin{array}{l}\text { Social, economic } \\
\text { and environmental }\end{array}$ & $\begin{array}{l}\text { PSR framework } \\
\text { classification }^{\#}\end{array}$ \\
\hline $\begin{array}{l}\text { China (Hualin, } \\
\text { 2001) }\end{array}$ & $\begin{array}{l}\text { City } \\
\text { (national) }\end{array}$ & $\begin{array}{l}\text { No; under } \\
\text { 'environment } \\
\text { sustainability' }\end{array}$ & Environmental & $\begin{array}{l}\text { As per different } \\
\text { aspects of } \\
\text { environment }\end{array}$ \\
\hline $\begin{array}{l}\text { EU Local } \\
\text { Sustainability } \\
\text { Indicator (EC, 2001) }\end{array}$ & $\begin{array}{l}\text { City } \\
\text { (regional) }\end{array}$ & $\begin{array}{l}\text { No; under } \\
\text { 'sustainable } \\
\text { development' }\end{array}$ & $\begin{array}{l}\text { Social, economic } \\
\text { and environmental }\end{array}$ & No classification \\
\hline $\begin{array}{l}\text { WBCSD Mobility } \\
\text { Indicators (Eads, } \\
\text { 2001) }\end{array}$ & $\begin{array}{l}\text { Regions } \\
\text { (global) }\end{array}$ & $\begin{array}{l}\text { Yes; under } \\
\text { 'sustainable mobility' }\end{array}$ & $\begin{array}{l}\text { Social, economic } \\
\text { and environmental }\end{array}$ & $\begin{array}{l}\text { Three dimensions: } \\
\text { social, economic } \\
\text { and } \\
\text { environmental }\end{array}$ \\
\hline Canada (CST, 2002) & Country & $\begin{array}{l}\text { Yes; under } \\
\text { 'sustainable } \\
\text { transportation } \\
\text { performance' }\end{array}$ & $\begin{array}{l}\text { Social, economic } \\
\text { and environmental }\end{array}$ & $\begin{array}{l}\text { As per different } \\
\text { aspects of } \\
\text { transportation }\end{array}$ \\
\hline $\begin{array}{l}\text { Kitakyushu (Dhakal, } \\
\text { 2002) }\end{array}$ & City & $\begin{array}{l}\text { No; under 'urban } \\
\text { environmental } \\
\text { sustainability' }\end{array}$ & $\begin{array}{l}\text { Social, economic } \\
\text { and environmental }\end{array}$ & $\begin{array}{l}\text { PSR framework } \\
\text { classification }^{\#}\end{array}$ \\
\hline
\end{tabular}

\footnotetext{
${ }^{16}$ This exercise in conjunction with discussion with different stakeholders resulted in set of potential indicators (listed in Table 5.2).
} 


\begin{tabular}{|c|c|c|c|c|}
\hline Initiative & Scope* & $\begin{array}{l}\text { Whether } \\
\text { exclusive to } \\
\text { transportation }\end{array}$ & $\begin{array}{l}\text { Transportation } \\
\text { dimension (s) } \\
\text { touched upon }\end{array}$ & $\begin{array}{l}\text { Classification of } \\
\text { indicators }\end{array}$ \\
\hline $\begin{array}{l}\text { Lyons (Nicolas et } \\
\text { al., 2003) }\end{array}$ & City & $\begin{array}{l}\text { Yes; under } \\
\text { 'Sustainable } \\
\text { transportation' }\end{array}$ & $\begin{array}{l}\text { Social, economic } \\
\text { and environmental }\end{array}$ & $\begin{array}{l}\text { Four dimensions: } \\
\text { mobility, social, } \\
\text { economic and } \\
\text { environmental }\end{array}$ \\
\hline London (2004) & City & $\begin{array}{l}\text { No; under 'quality of } \\
\text { life' }\end{array}$ & $\begin{array}{l}\text { Social, economic } \\
\text { and environmental }\end{array}$ & $\begin{array}{l}\text { As per different } \\
\text { aspects of quality } \\
\text { of life }\end{array}$ \\
\hline $\begin{array}{l}\text { Seattle } \\
\text { (Sustainable Seattle, } \\
2004)^{\wedge}\end{array}$ & City & $\begin{array}{l}\text { No; under } \\
\text { 'sustainable } \\
\text { community' }\end{array}$ & $\begin{array}{l}\text { Social, economic } \\
\text { and environmental }\end{array}$ & $\begin{array}{l}\text { As per different } \\
\text { aspects of } \\
\text { community life }\end{array}$ \\
\hline UNCHS (2004) & $\begin{array}{l}\text { City } \\
\text { (global) }\end{array}$ & $\begin{array}{l}\text { No; under 'habitat } \\
\text { agenda' and MDGs }\end{array}$ & $\begin{array}{l}\text { Economic and } \\
\text { environmental }\end{array}$ & $\begin{array}{l}\text { As per habitat } \\
\text { agenda goals }\end{array}$ \\
\hline Cape Town (2006) & City & $\begin{array}{l}\text { Yes; under } \\
\text { 'Sustainable } \\
\text { transportation' }\end{array}$ & $\begin{array}{l}\text { Social, economic } \\
\text { and environmental }\end{array}$ & $\begin{array}{l}\text { Three dimensions: } \\
\text { social, economic } \\
\text { and } \\
\text { environmental }\end{array}$ \\
\hline $\begin{array}{l}\text { Nova Scotia (GPI, } \\
\text { 2006) }\end{array}$ & $\begin{array}{l}\text { Province } \\
\text { (region of } \\
\text { country) }\end{array}$ & $\begin{array}{l}\text { Yes; under 'Genuine } \\
\text { Progress Index (GPI) } \\
\text { transportation } \\
\text { accounts' }\end{array}$ & $\begin{array}{l}\text { Social, economic } \\
\text { and environmental }\end{array}$ & $\begin{array}{l}\text { Four dimensions - } \\
\text { mobility, social, } \\
\text { economic and } \\
\text { environmental }\end{array}$ \\
\hline UK (2006) & Country & $\begin{array}{l}\text { No; under } \\
\text { 'sustainable } \\
\text { development' }\end{array}$ & $\begin{array}{l}\text { Social, economic } \\
\text { and environmental }\end{array}$ & $\begin{array}{l}\text { As per identified } \\
\text { priority areas }\end{array}$ \\
\hline India (CSTI, 2007) & $\begin{array}{l}\text { City } \\
\text { (national) }\end{array}$ & $\begin{array}{l}\text { Yes; under 'transport } \\
\text { and air quality' }\end{array}$ & $\begin{array}{l}\text { Social, economic } \\
\text { and environmental }\end{array}$ & $\begin{array}{l}\text { As per different } \\
\text { aspects of } \\
\text { economy and } \\
\text { transportation }\end{array}$ \\
\hline $\begin{array}{l}\text { Texas (Ramani et } \\
\text { al., 2009) }\end{array}$ & City & $\begin{array}{l}\text { Yes; under } \\
\text { 'Sustainable } \\
\text { transportation' }\end{array}$ & $\begin{array}{l}\text { Social, economic } \\
\text { and environmental }\end{array}$ & $\begin{array}{l}\text { As per strategic } \\
\text { goals }\end{array}$ \\
\hline $\begin{array}{l}\text { European Union } \\
\text { (EEA, 2010) }\end{array}$ & $\begin{array}{l}\text { Country } \\
\text { (regional) }\end{array}$ & $\begin{array}{l}\text { Yes; under 'resource } \\
\text { efficient } \\
\text { transportation } \\
\text { system' }\end{array}$ & $\begin{array}{l}\text { Social, economic } \\
\text { and environmental }\end{array}$ & $\begin{array}{l}\text { As per different } \\
\text { aspects of } \\
\text { transportation }\end{array}$ \\
\hline New Zealand (2011) & Country & $\begin{array}{l}\text { Yes; under 'transport } \\
\text { monitoring indicator' }\end{array}$ & $\begin{array}{l}\text { Social, economic } \\
\text { and environmental }\end{array}$ & $\begin{array}{l}\text { As per different } \\
\text { aspects of } \\
\text { transportation }\end{array}$ \\
\hline
\end{tabular}

Notes: \# Pressure-state-response (PSR) framework, developed and popularized by OECD (2003) is such a conceptual approach widely used in SDI initiatives. 'Pressure' indicators represent human activities, processes, and patterns that impact on sustainable development either positively or negatively. 'State' indicators provide a reading on the present state of affairs, while 'response' indicators are societal actions aimed at reducing sustainability risks and pursuing sustainable development.

${ }^{+}$System framework, based on extended urban metabolism model (EUMM), has been developed by Newman et al. (1996). EUMM views cities as systems requiring key resources which are drawn into the urban processes and transforming them into desirable outputs (livability) and waste.

${ }^{\wedge}$ This has been referenced as Sustainable Seattle (2004)

* Coverage of the program is provided in parenthesis when it does not match with scope 


\section{Mumbai - the City under Study}

The rationale of choice of Mumbai as the city under study is manifold. ${ }^{17}$ Mumbai is the biggest city in India, population wise (MCGM, 2010). It is the second most populous city in the world after Shanghai (World Gazetteer, 2011). The population growth and growth rate of Mumbai are given in Figure 1. The growth rate of population has declined during 1971-2001. Since 1981, Mumbai has been growing at a slower pace compared to average urban India. The population is projected to grow between 15 and 21 million by 2030 (MCGM, 2010).

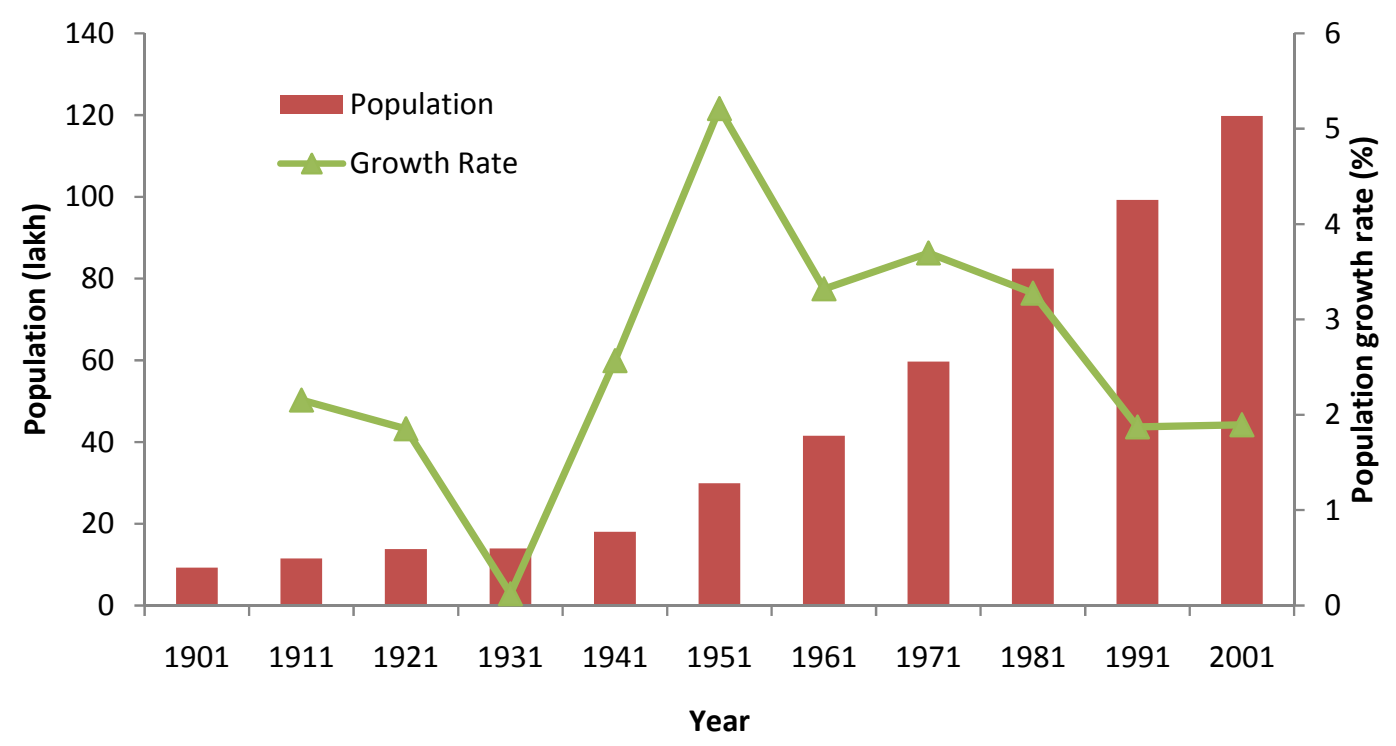

Source: MCGM (2010) [Primary source: India’s census data from 1901 to 2001]

Figure 1 Population, and population growth rate in Mumbai: 1901-2001

Mumbai is not only the most populous city of India, it the densest (MCGM, 2009). It has a land area of 466.35 sqkm and a population density of 43,583 per sq $\mathrm{km}$. About $60 \%$ of the people of Mumbai live in slums. The shortage of land and high population density throws multitude of challenges to the transportation sector of the city. Despite $80 \%$ of commuters using public transport, the congestion is still high on Mumbai roads due to high traffic density

\footnotetext{
${ }^{17}$ Apart from the coincidence of its location, (i.e., IGIDR is being in the same city), Mumbai-the financial capital of country- has been chosen for the current study as it is the most populous city of India with migrants from all over the country making the place a congregation of various communities and cultures. Both poverty and wealth are in ample and extremities and so is the resource use pattern. This wider spectrum of socioeconomic standards in people of Mumbai makes it an interesting case to study.
} 
(MCGM, 2010). The high traffic volume and infrastructure constrains in Mumbai get reflected by the fact that $75 \%$ of the road fatalities are of pedestrians (World Bank, 2002).

Mumbai is equipped with both bus and train services, which is considered superior compared to other Indian cities (Pucher et al., 2005). The popular and environmentally clean mode of public transport is electrically operated suburban railways; it is punctual and purposeful, but overcrowded (MCGM, 2009; MCGM, 2010). The rail network consists of two suburban systems, namely, Central Railway and Western Railway, spanning for 319 km and carrying close to 700,000 population daily (MMRDA, 2009). The environment friendly suburban rail transport has a big question mark on the safety and security of the passengers with approx 4,000 people dying every year on travel (MCGM, 2010). The BEST (Bombay Electric Supply \& Transport) operates 3,587 buses on 370 routes carrying 43,000 passengers daily (MCGM, 2010).

With inputs from various studies by leading organizations like World Bank, UNEP/WHO, TERI, CPCB (2010) has reported that for Mumbai transportation sector contributes $92 \%$ of the carbon monoxide $(\mathrm{CO}), 60 \%$ of nitrogen oxides $\left(\mathrm{NO}_{\mathrm{X}}\right)$, up to $16 \%$ of particulate matter and up to $4 \%$ of sulphur dioxide $\left(\mathrm{SO}_{2}\right)$ to the city. The large population base, high population density, land and infrastructural constraints, road congestions, overcrowding in trains, and safety and security challenges of the commuters makes Mumbai as an interesting case study for transportation sustainability. The socio-economic characteristics of the city make it all the more interesting. Mumbai is the financial capital having majority of populace as slum dwellers; it exults its wealth and at the same time faces the impact of urban poverty, dwarfing other major India cities in its extent and complexity (MCGM, 2010).

\section{Application of MVBB Framework to Transportation Sector}

Literature has considered different frameworks to assess the sustainability of transportation through indicators, ${ }^{18}$ and there is no single standard framework (Jeon and Amekudzi, 2005). Here, we will enforce the MVBB framework developed in Nathan and Reddy (2011a). MVBB framework is a modification on systems framework where first, a black-box model is introduced by eliminating the system dynamics component from conventional EUMM model

\footnotetext{
${ }^{18}$ For example of different sustainable development indicator initiatives in transportation, see Black et al (2002), Jeon and Amekudzi (2005), Richardson (2005), among others.
} 
and then, a three-dimensional view-economic efficiency (EE), social wellbeing (SW) and ecological acceptability (EA) — is employed on the model to incorporate the sustainable development paradigm (Nathan and Reddy, 2011a). The basic sustainability goal in systems framework, i.e., the futuristic agenda of 'reduced input', 'greater livability' and 'reduced waste’, remains same for MVBB framework.

Figure 2 shows application of MVBB framework to transportation sector. The framework treats the urban transportation sector as a black-box and focuses on the observable parameters at the boundary through its three views, namely, economic efficiency (EE-view), social wellbeing (SW-view) and ecological acceptability (EA-view).

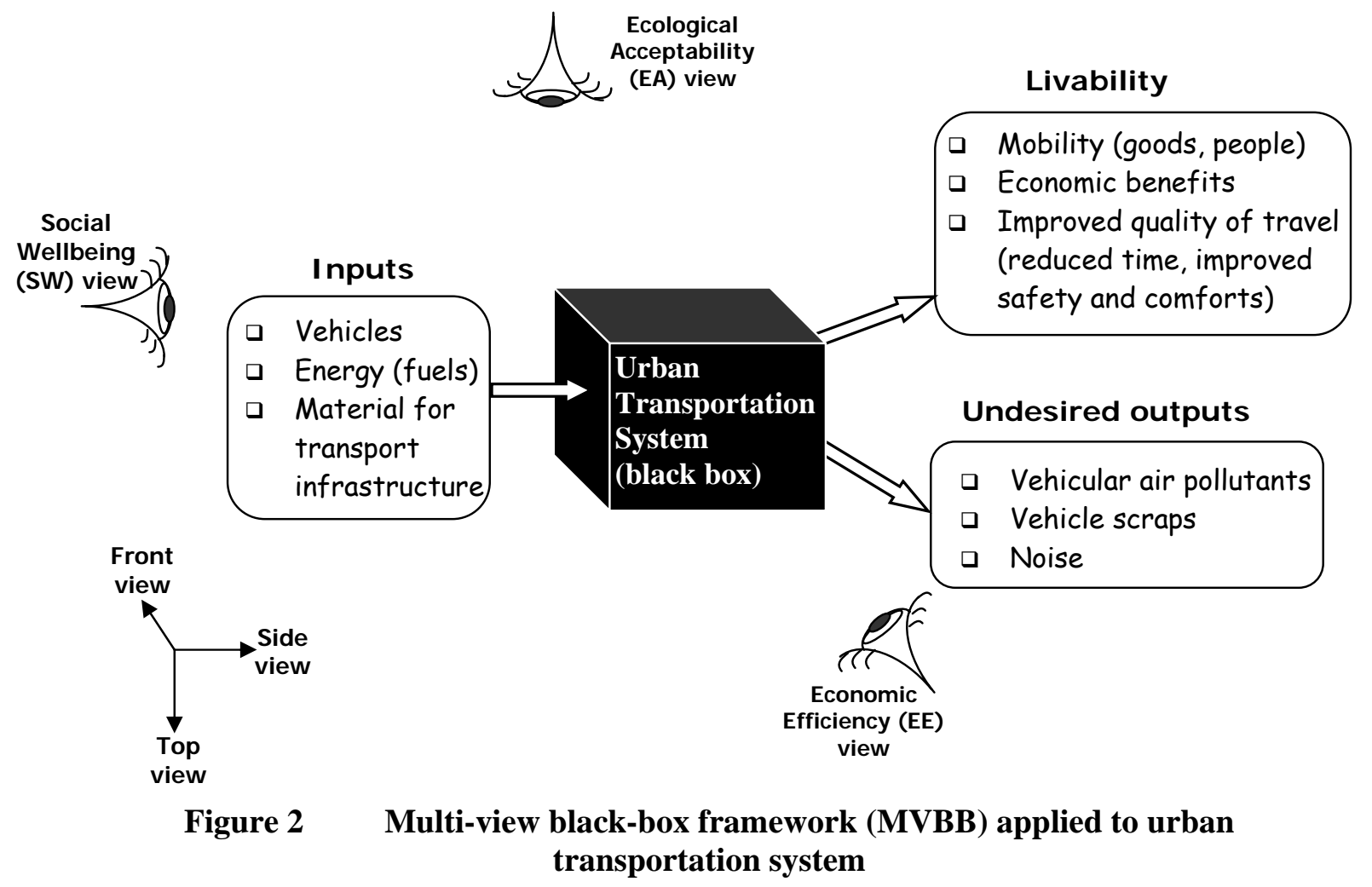

The input resources to transportation sector are vehicles, energy carriers like petrol and diesel to fuel the vehicles, and the material to construct roads and rail networks. The desired output or livability means the optimal mobility of goods and people leading to greater accessibility to workplace, school, hospital, market, recreation and other basic services with 'healthier' and comfortable travel. The undesirable output or waste includes air pollutants, traffic noise, solid waste and accidents. The goal of sustainable transportation under MVBB is to achieve 
greater livability with reduced resource inputs and reduced waste through higher efficiency, greater wellbeing and better environmental compatibility. ${ }^{19}$ In order to capture sustainable development indicators (SDIs), the transportation system is subjected to the following three simultaneous views.

EE (Economic efficiency) view: This view looks into the energy efficiency, financial efficiency and also, infrastructural and system efficiency of the transportation sector of the city. Economic sustainability requires that resources be used efficiently and that assets be maintained properly.

SW (Social wellbeing) view: This view constitutes equity in transportation, extent of public transportation, and impact on public health on account of transportation. Social sustainability requires that the benefits of improved transport reach all the sections of the community.

EA (Environmental acceptability) view: This view signifies pollution reduction, waste recycling, and diffusion of clean technologies. Environmental and ecological sustainability requires that the external effects of transport be taken into account fully when public or private decisions are made that determine future development.

There can be conceptual overlap across these three views, which means an indicator may have relevance to more than one of the three views. Therefore, while evaluating the indicator, its relevance both to the view under which it is grouped and to overall sustainability must be considered.

\section{Potential SDls for Transportation System of Mumbai}

The idea of considering a potential list of indicators and applying a set of criteria to arrive at the final list is prevalent in the indicator research. Table 2 gives the potential list of indicators pertinent to Mumbai transportation system. ${ }^{20}$ This list has been prepared by revisiting the indicator initiatives listed in the Section 3 (Table 1) and considering the indicators which has relevance in the context of Mumbai.

\footnotetext{
${ }^{19}$ A similar spirited goal for transportation system has been put forwarded by Schiller et al. (2010, p. xxi)

${ }^{20}$ The exercise of asserting the final list of indicators is out of the scope of this paper. This exercise is being attempted in a companion paper.
} 
Table 2 Potential SDIs for Mumbai Transportation System

\begin{tabular}{|c|c|c|c|}
\hline Code & POTENTIAL INDICATORS & INDICATION & INSTANCES OF USE \\
\hline \multicolumn{4}{|c|}{ Economic efficiency EE-view indicators } \\
\hline EE01 & $\begin{array}{l}\text { Transport energy efficiency } \\
\text { (Monetary) } \\
\quad \frac{\text { NDDP from transport sector }}{\text { Energy use in Transport }} \\
\text { NDDP: Net District Domestic Product } \\
\text { This indicator will be calculated for (i) } \\
\text { Road, (ii) Rail, and (iii) Total }\end{array}$ & $\begin{array}{l}\text { This indicates how productively (in } \\
\text { economic terms) the input energy resources } \\
\text { are used. The higher the value of the } \\
\text { indicator the better it is. }\end{array}$ & Australia (1998) \\
\hline EE02 & $\begin{array}{l}\text { Transport energy efficiency (Utility) - } \\
\text { mode wise } \\
\quad \frac{\text { Passenger km travelled (PKT) }}{\text { Energy use }} \\
\text { This indicator will be calculated for (i) } \\
\text { Public Tran (combining rail and bus), } \\
\text { (ii) Private Trans, and (iii) difference }\end{array}$ & $\begin{array}{l}\text { This indicates how productively (in service } \\
\text { utility terms) the input energy resources are } \\
\text { used for different modes of transport. The } \\
\text { PKT values are to be estimated, which brings } \\
\text { in subjectivity to the indicator. It would be } \\
\text { interesting to note the gap in energy } \\
\text { efficiency of public and private transport. }\end{array}$ & $\begin{array}{l}\text { OECD (2000c), Finland (OECD, } \\
2000 a) \text {, Italy (OECD, 2000b), Nova } \\
\text { Scotia (GPI, 2006), EU (EEA, 2010), } \\
{ }^{21} \text { New Zealand (2011) }\end{array}$ \\
\hline
\end{tabular}

EE03 Transport energy efficiency (Utility) category wise

$\frac{\text { Passenger } \mathrm{km} \text { travelled }(P K T)}{\text { Energy use }}$

This indicator will be calculated for (i) 2Wheeler, (ii) 3Wheeler, (iii)

Cars/Jeeps/Taxis, (iv) Buses, (v) Rails, and (vi) goods-TKT/Energy

EE04 Transport monetary efficiency (Utility)-category wise Passenger km travelled (PKT) Energy expenses This indicator will be calculated for (i) 2Wheeler, (ii) 3Wheeler, (iii) Cars/Jeeps/Taxis, (iv) Buses, (v) Rails, and (vi) goods-TKT/Energy expenses

Per capita energy consumption in transportation

Energy use in transportation Total population

This indicator will be calculated for (i) Road and (ii) Rail, and (iii) Total

Per capita road length $\frac{\text { Total raod length }}{\text { Total population }}$ efficiency of public and private transport.

Fis indicates how productively (in service (OECD, 2000a), Italy (OECD utility terms) the input energy resources are 2000b), Canada (CST, 2002) ${ }^{22}$ used for different categories of vehicles. The higher the value of the indicator the better it is. The PKT values are to be estimated, which brings in subjectivity to the indicator.

This indicates the return of the monetary $\operatorname{OECD}(2000 \mathrm{c})^{23}$, Italy (OECD, expenses (on fuel use) for travel under each 2000b) category of vehicles. The higher the value of the indicator the better it is. Indicator

possesses the limitation of PKT being estimation dependent. Additionally, the indicator needs to be adjusted for changing value of money.

This signifies energy intensiveness of the city. Lower value of the indicator signifies more efficient use of energy, or better OECD (2000c), Italy (OECD, 2000b), Seattle (2004), Nova Scotia (GPI, planning of the city with provision of public transport. $^{24}$

This indicates the availability of road in the city. A very low value would indicate 2006), Cape Town (2006) ${ }^{25}$, India (CSTI, 2007), New Zealand (2011)

OECD (2000c), Italy (OECD, 2000b)

${ }^{21}$ EU (EEA, 2010) and Nova Scotia (GPI, 2006) have considered energy efficiency in terms of VKT.

${ }^{22}$ CST (2002) looks into energy per unit cumulative VKT considering cars and trucks together.

${ }^{23}$ For OECD (2000c) the indicator transport intensity is calculated by dividing transport utility (PKT) by the GDP of the country. In that way this indicator shows the transport dependency of the country's economy. However, here a different indicator 'EE16 - contribution of transport sector to the GDP' is used for the same purpose.

${ }^{24}$ The significance of the lower value of the indicator may sometimes signal inadequate provision of transport facility at the first place, which of course is not true for Mumbai.

${ }^{25}$ Cape Town (2006) considers total energy, not per capita. 


\section{Code POTENTIAL INDICATORS}

EE07

Vehicles per road length-category

wise

$$
\frac{\text { Total number of vehicles }}{\text { Total raod length }}
$$

This indicator will be calculated for (i)

2Wheeler, (ii) 3Wheeler, (iii)

Cars/Jeeps/Taxis, (iv) Buses, (v) Goods

vehicle, and (vi) Other vehicles

Vehicles per 1000 population Total number of vehicles Total population

This indicator will be calculated for (i) Private, (ii) Public, and (iii) Total

VKT per population-road, rail

Total Vehicles km travelled (VKT) Total population

EE10

VKT proportion - mode and category wise

This indicator will be calculated for (i) 2Wheeler, (ii) 3Wheelers, (iii) Cars/Jeeps/Taxis, (iv) Buses, (v) Goods vehicle, (vi) Other vehicles, (vii) Total Private, (viii) Total Public, and (ix) Rails

EE11

PKT per population - mode and category wise

Total Passemger km travelled (PKT)

$$
\text { Total population }
$$

EE12 PKT proportion - mode/category wise This indicator will be calculated for (i) 2Wheeler, (ii) 3Wheelers, (iii) Cars/Jeeps/Taxis, (iv) Buses, (v) Goods vehicle, (vi) Other vehicles, (vii) Total, Private, (viii) Total Public, and (ix) Rails

EE13

Average speed of transport -category wise

This indicator will be calculated for (i) 2Wheeler, (ii) 3Wheelers, (iii) Cars/Jeeps/Taxis (iv) Buses (v) Goods vehicle (vi) Rails

EE14 \% of road length double or more lane in total

EE15 \% of road length having street lighting

\section{INDICATION}

congestion, a very high value over-

construction of roads. ${ }^{26}$

This indicates vehicle density. To attain a lower level congestion on the roads, this value must be lower.
INSTANCES OF USE

Kitakyushu (Dhakal, 2002)
This indicates vehicle ownership. Increasing private vehicle ownership together with decreasing public vehicle ownership would mean falling public transport infrastructure, which when continued is not sustainable.

This indicates the extent of vehicle use or mobility in the society. For this indicator VKT value needs to be estimated.

This indicator will show whether VKT is biased towards any particular mode of transport (private or public) or any 'category' of vehicle (2/3wheelers, cars, buses, rails). A higher proportion of public transport is desired for a sustainable society.

This indicates passengers' motorized mobility in the society. Here, PKT value needs to be estimated.

This indicator will show whether the PKT is biased towards any particular mode of transport (private or public) or any 'category' of vehicle (2wheelers, 3wheelers, cars, buses, rails). A higher proportion of public travel is better for a sustainable society.

This indicates the level of technology and congestion. A congestion-free fast mobility reduces time of travel and (most of the time) makes it more comfortable.
Australia (1998), Bologna (2000), OECD (2000c), Italy (OECD, 2000b), Italy (Donatiello, 2001), Kitakyushu (Dhakal, 2002), Cape Town (2006), Nova Scotia (GPI, 2006), India (CSTI, 2007), EU (EEA, 2010), New Zealand (2011)

London (2004), Seattle (2004), UNCHS (2004), Nova Scotia (GPI, 2006), New Zealand (2011) Bologna (2000), Italy (OECD, 2000b), Canada (CST, 2002), UK (2006) , New Zealand (2011)

UNCSD (1996), EC (2001), Canada (CST, 2002), Nova Scotia (GPI, 2006), UK (2006)

Bologna (2000), Italy (OECD, 2000b), Canada (CST, 2002), India (CSTI, 2007), ${ }^{27}$ EU (EEA, 2010)

Italy (OECD, 2000b), EC (2001), WBCSD (Eads, 2001), Lyons (Nicolas et al., 2003), USDOT (2003), UNCHS (2004), Texas (Ramani et al., 2009), New Zealand (2011)

\footnotetext{
${ }^{26}$ Considering Mumbai's case of congested roads and large number of vehicles, the higher the value of the indicator, the better it is.

${ }^{27}$ CSTI (2007) has considered modal splits for the passengers, not exactly PKT.
} 


\begin{tabular}{|c|c|c|c|}
\hline Code & POTENTIAL INDICATORS & INDICATION & INSTANCES OF USE \\
\hline & & case in Mumbai & \\
\hline EE16 & $\begin{array}{l}\text { Contribution of Transportation sector } \\
\text { to economy (i) \% of GDP and (ii) \% of } \\
\text { employment }\end{array}$ & $\begin{array}{l}\text { This indicates the macroeconomic aspect of } \\
\text { the transportation sector; the higher the } \\
\text { values, greater is the importance of the } \\
\text { sector. }\end{array}$ & New Zealand (2011) \\
\hline EE17 & $\begin{array}{l}\text { Earnings and expenses per PKT in } \\
\text { Public Tran. For (i) Bus, and (ii) Rails }\end{array}$ & $\begin{array}{l}\text { This indicates the financial sustainability of } \\
\text { the public transportation system. The value } \\
\text { need to be optimal; too high would negate } \\
\text { the service-motive, too low would make } \\
\text { financially unsustainable. }\end{array}$ & WBCSD (Eads, 2001) \\
\hline EE18 & $\begin{array}{l}\text { Public parking space per ' } 000 \text { vehicle - } \\
\text { category wise }\end{array}$ & $\begin{array}{l}\text { This indicates the availability of parking } \\
\text { space in the city. }\end{array}$ & $\begin{array}{l}\text { Italy (Donatiello, 2001), Lyons } \\
\text { (Nicolas et al., 2003), Cape Town } \\
(2006)^{29}\end{array}$ \\
\hline EE19 & $\begin{array}{l}\text { No. of potholes per km of road length } \\
\text { - during (i) Rains (ii) Non rainy }\end{array}$ & This indicates quality of roads. & New Zealand $(2011)^{30}$ \\
\hline
\end{tabular}

\section{Social wellbeing $S W$-view indicators}

SW01 Share of Commuters using Public Transport

Commuters using public transport

Total no. of commuters

This indicates the use of public transport by commuters; the higher the value of the indicator the better it is. Total number of commuters needs to be estimated.

SW02 Share of Public Transport in total $\frac{\text { PKT (public transport) }}{\text { PKT (total) }}$

SW03 Share of Rail commuters in public transport

$$
\frac{\text { No.of commuters in Rail }}{\text { Total no.of public transport }}
$$

SW04 Average HH Expenditure

$$
\frac{M P C E \text { transport }}{\text { Total MPCE }}
$$

MPCE: Monthly per capita consumption expenditure

SW05 Inequality in HH exp. on transportation among income groups This indicator can be formulated like Gini Inequality index

Sw06 No. of accidental deaths

(i) Rail (Number, per million VKT)

(ii) Road (Number, per million VKT)

SW07 No. of accidental injuries on Road (Number, per million VKT) of bus. The higher the share of rail in public transport, the better it is.
This is an indicator of safe transport. The lower the value of the indicator, the better it is.

This indicates the affordability of travel expenses. The lower the value of the indicator, the better it is.

This indicates the inequality in affordability of the travel expenses across income groups.

This is an indicator of safe transport. The lower the value of the indicator, the better it is.

This indicates the share of public transport; Kitakyushu (Dhakal, 2002)

the higher the value of the indicator the better it is. PKT value needs to be estimated.

Rail transport is considered faster, and
friendlier to environment compared to that

Italy (Donatiello, 2001), Cape Town (2006), Nova Scotia (GPI, 2006), New Zealand (2011)

New Zealand (2011)

Canada (CST, 2002), Lyons (Nicolas et al., 2003), Cape Town (2006), Nova Scotia (GPI, 2006), India (CSTI, 2007), New Zealand (2011)

EU (EEA, 2010)

Australia (1998), Bologna (2000), Italy (OECD, 2000b), WBCSD (Eads, 2001), Canada (CST, 2002), USDOT (2003), Nova Scotia (GPI, 2006), UK (2006), India (CSTI, 2007), EU (EEA, 2010), New Zealand (2011)

Australia (1998), Bologna (2000), Italy (OECD, 2000b), WBCSD (Eads, 2001), Canada (CST, 2002), Nova Scotia (GPI, 2006), UK (2006), India (CSTI, 2007), New Zealand (2011)

\footnotetext{
${ }^{28}$ Too high a value may mean significant portion of land going simply for parking.

${ }^{29}$ Cape Town (2006) considers parking space per capita.

${ }^{30}$ New Zealand (2011) measures the quality of roads, not exactly potholes.
} 


\begin{tabular}{cl}
\hline Code & POTENTIAL INDICATORS \\
\hline SW08 & $\begin{array}{l}\text { No. of People having driving license } \\
\text { (not public transport type) per } 1000 \\
\text { pop. }\end{array}$
\end{tabular}

SW09 \% road length having footpath

SW10 \% of footpath encroached

SW11 No. of drunk driving cases registered per year

SW12 No. of unsafe driving registered (Signal jump, without license etc) per year

SW13 Proportion of service disability compliant (i) \% of bus fleet, and (ii) \% of railway stations

SW14 \% school children using private transport

SW15 \% employees of organized sector using private transport

SW16 Hearing impairment due to traffic noise (affected per 1 lakh population)

SW17 Respiratory diseases due to vehicular pollutants (affected per 1000 population)

SW18 Proportion of people exposed to (i) vehicular pollution, and (ii) traffic noise
INDICATION

INSTANCES OF USE

Higher number of driving licenses indicates Australia (1998)

greater tendency towards the use of

motorized transport. The lower the value of the indicator, the better it is.

The population using public transport use footpath as they typically walk to the Bologna (2000), Italy (Donatiello, 2001), Canada (CST, 2002), USDOT destination from the public transport stops. (2003), Seattle (2004), Nova Scotia This indicator signifies the importance given (GPI, 2006), New Zealand (2011) to the walking population in transport plan. The higher the value of the indicator, the better it is.

This indicates the importance given to the walking population in road management. The lower the value of the indicator, the better it is.

This signifies the social responsibility of motorists. The case of drunken driving is not uncommon in Mumbai. This indicator would check the trend. ${ }^{32}$

This is an indication of how much traffic discipline drivers maintain in the city. ${ }^{33}$

This indicates the sensitivity of the

USDOT (2003) transportation system to the needs of the physically handicapped people.

Going to school, being an important need of EC (2001), London (2004), UK transportation-this indicator signals the prevalence of private transport in the city. (2006), Nova Scotia (GPI, 2006) $)^{34}$, New Zealand (2011) The lower the value of the indicator the better it is.

Going to school, being an important need of Nova Scotia (GPI, 2006), New transportation - this indicator signals Zealand (2011)

prevalence of private transport in the city. A lower value signifies a better situation.

This indicates negative health impact due to USEPA(1996), New Zealand noise pollution on account of traffic.

$(2011)^{35}$

This indicates negative health impact due to USEPA(1996), New Zealand air pollution on account of transportation.

$(2011)^{36}$

This signifies the health risks due to vehicular pollution and traffic noise.
USEPA(1996), OECD (2000c), Finland (OECD, 2000a), Italy (OECD, 2000b), EC (2001), EU (EEA, 2010),

${ }^{31}$ Texas (Ramani et al., 2009) looks into the condition of footpath, not exactly encroachment. Similarly, New Zealand (2011) measures the quality of footpath, not exactly encroachment.

32 A decreasing trend may not always mean falling consumption of alcohol while driving. A lack of traffic vigilance by the police may also lead to fall in such cases.

${ }^{33}$ A decreasing trend may not always mean falling instances of unsafe driving. A lack of traffic vigilance by the police may also lead to fall in such cases.

${ }^{34}$ Nova Scotia (GPI, 2006) considers number of children walking to the school.

${ }^{35}$ New Zealand (2011) accounts for social cost of traffic noise, not exactly hearing impairment

${ }^{36}$ New Zealand (2011) accounts for social cost of transport induced air pollution, not exactly respiratory disease. 


\begin{tabular}{cc}
\hline Code & POTENTIAL INDICATORS \\
\hline & \\
\hline EA01 & $\begin{array}{c}\text { Vehicle share with cleaner fuels: } \\
\text { No. of veicles wit CNG or } L N G\end{array}$ \\
& \multicolumn{1}{c}{ Total no. of vehicles } \\
& $\begin{array}{l}\text { This indicator will be calculated for (i) } \\
\text { 3Wheelers, (ii) Cars/Jeeps/Taxis, and } \\
\text { EA02 }\end{array}$ \\
& $\begin{array}{l}\text { Share of } 2 \text { Buses } \\
\text { stroke engines: }\end{array}$ \\
& $\frac{\text { Two wheelers hhh (four stroke) }}{\text { Total no. of two wheelers }}$
\end{tabular}

EA03 Proportion of mobile population using This indicates the extent of use of motorized Nova Scotia (GPI, 2006), ${ }^{38}$ Cape

This is an indication of movement towards less polluting technology in transportation. This indicator is considered as two wheelers are a significant mode of transport in India. non motorized transport (walking or cycling)

$\frac{\text { Population walking or cycling }}{\text { Total mobile population }}$

EA04 Carbon Monoxide (CO) emission per day

transport in the city. A higher value indicates better situation.

This is an indicator of transportation induced urban air pollution. This pollutant results out of incomplete combustion of fuels, more prone from petrol run vehicles. $\mathrm{CO}$ has direct health effect and indirect effect on climate change (CPCB, 2010). CO is considered as an Air Quality standard monitoring parameter by India's Central Pollution Control Board (CPCB) (2009). The lower the value of the indicator, the better it is.

EA05 Nitrogen Dioxides $\left(\mathrm{NO}_{2}\right)$ emission per day

EA06 Sulfur Dioxide $\left(\mathrm{SO}_{2}\right)$ emission per day

Particulate Matter per day impact on health and climate change and is responsible for acid rain, euthrophication and poor visibility (CPCB, 2010). This considered as a standard air quality parameter by OECD (2002) and CPCB (2009). The lower the value of the indicator, the better it is.

$\mathrm{SO}_{2}$ is an urban transportation pollutant emitted mostly by diesel vehicle. It is responsible for acid rain apart from adverse health and climate impacts. A lower value indicates a better situation.

This indicates the emission of fine particles (less than 10 micron in diameter) from vehicular exhaust. This is considered as a standard air quality parameter by OECD (2002) and CPCB (2009). Particulate matter
Town (2006), India (CSTI, 2007), New Zealand (2011)

UNCSD (1996), USEPA(1996), Bologna (2000), OECD (2000c), Finland (OECD, 2000a), Italy (OECD, 2000b), EC (2001), WBCSD (Eads, 2001), Canada (CST, 2002), Lyons is (Nicolas et al., 2003), Seattle (2004), Nova Scotia (GPI, 2006), EU (EEA, 2010)

UNCSD (1996), USEPA(1996), Bologna (2000), OECD (2000c), Finland (OECD, 2000a), Italy (OECD, 2000b), China (Hualin, 2001), EC (2001), WBCSD (Eads, 2001), Canada (CST, 2002), Lyons (Nicolas ). et al., 2003), Nova Scotia (GPI, 2006), UK (2006), India (CSTI, 2007), Texas (Ramani et al., 2009), EU (EEA, 2010) UNCSD (1996), USEPA(1996), Finland (OECD, 2000a), Italy (OECD, 2000b), China (Hualin, 2001), EC (2001), WBCSD (Eads, 2001), Kitakyushu (Dhakal, 2002), Canada (CST, 2002), Nova Scotia (GPI, 2006), UK (2006), India (CSTI, 2007)

UNCSD (1996), USEPA(1996) Bologna (2000), OECD (2000c), Finland (OECD, 2000a), Italy (OECD, 2000b), China (Hualin, 2001), EC (2001), WBCSD (Eads, 2001),

\footnotetext{
${ }^{37}$ The indicator for Bologna (2000) is share of pollution controlled vehicles.

${ }^{38}$ Nova Scotia (GPI, 2006) considers passenger km of non motorized transport.
} 


\begin{tabular}{|c|c|c|c|}
\hline Code & POTENTIAL INDICATORS & INDICATION & INSTANCES OF USE \\
\hline & & $\begin{array}{l}\text { has adverse health effects. A lower value } \\
\text { indicates a better situation. }\end{array}$ & $\begin{array}{l}\text { Kitakyushu (Dhakal, 2002), Lyons } \\
\text { (Nicolas et al., 2003), London } \\
\text { (2004), Seattle (2004), Nova Scotia } \\
\text { (GPI, 2006), UK (2006), India (CSTI, } \\
\text { 2007), Texas (Ramani et al., 2009), } \\
\text { EU (EEA, 2010) }\end{array}$ \\
\hline EA08 & Volatile Organic Compounds per day & $\begin{array}{l}\text { This indicates transport induced air } \\
\text { pollution. This considered as a standard air } \\
\text { quality parameter by OECD ( } 2002) \text {. A lower } \\
\text { value indicates a better situation. }\end{array}$ & $\begin{array}{l}\text { UNCSD (1996), USEPA(1996), } \\
\text { Bologna (2000), OECD (2000c), Italy } \\
\text { (OECD, 2000b), WBCSD (Eads, } \\
\text { 2001), Canada (CST, 2002), } \\
\text { Kitakyushu (Dhakal, 2002), Nova } \\
\text { Scotia (GPI, 2006), Texas (Ramani } \\
\text { et al., 2009), EU (EEA, 2010) }\end{array}$ \\
\hline EA09 & Lead $(\mathrm{Pb})$ per day & $\begin{array}{l}\text { Lead transportation induced pollutant } \\
\text { emanating from petrol vehicles. It has } \\
\text { various health hazards (CPCB, 2010). A } \\
\text { lower value indicates a better situation. }\end{array}$ & UNCSD (1996), USEPA(1996) \\
\hline EA10 & Hydrocarbon (HC) per day & $\begin{array}{l}\mathrm{HC} \text { is a transport emission pollutant having } \\
\text { direct health and indirect climate impacts } \\
\text { (CPCB, 2010). A lower value indicates a } \\
\text { better situation. }\end{array}$ & $\begin{array}{l}\text { WBCSD (Eads, 2001), Kitakyushu } \\
\text { (Dhakal, 2002), Lyons (Nicolas et } \\
\text { al., 2003), Texas (Ramani et al., } \\
\text { 2009) }\end{array}$ \\
\hline EA11 & $\begin{array}{l}\text { Toxic Substances (Benzene, Butadiene } \\
\text { and Formaldehyde) per day }\end{array}$ & $\begin{array}{l}\text { This transportation induced toxic pollution } \\
\text { has detrimental health effects in high } \\
\text { exposure areas (CPCB, 2010). A lower value } \\
\text { indicates a better situation. }\end{array}$ & $\begin{array}{l}\text { UNCSD (1996), USEPA(1996), Italy } \\
\text { (OECD, 2000b) }\end{array}$ \\
\hline EA12 & $\begin{array}{l}\text { Greenhouse emissions (Carbon } \\
\text { Dioxide }\left(\mathrm{CO}_{2}\right) \text {, Methane }\left(\mathrm{CH}_{4}\right) \text {, Nitrous } \\
\left.\text { Oxide } \mathrm{N}_{2} \mathrm{O}\right)\end{array}$ & $\begin{array}{l}\text { Stabilization of Greenhouse emissions has } \\
\text { direct relation to climate protection. } \mathrm{CO}_{2} \\
\text { concentration has been identified as a } \\
\text { criterion by Environmentally Sustainable } \\
\text { Transport (EST) program (OECD, 2002). A } \\
\text { lower value indicates a better situation. }\end{array}$ & $\begin{array}{l}\text { USEPA(1996), Bologna (2000), } \\
\text { OECD (2000c), Finland (OECD, } \\
\text { 2000a), Italy (OECD, 2000b), } \\
\text { WBCSD (Eads, 2001), Canada (CST, } \\
\text { 2002), London (2004), Nova Scotia } \\
\text { (GPI, 2006), Lyons (Nicolas et al., } \\
\text { 2003), Cape Town (2006), UK } \\
\text { (2006), Texas (Ramani et al., 2009), } \\
\text { EU (EEA, 2010), New Zealand } \\
\text { (2011) }\end{array}$ \\
\hline EA13 & Traffic Noise Level & $\begin{array}{l}\text { This is an indicator of noise pollution. A } \\
\text { lower value indicates a better situation. This } \\
\text { indicator has been considered as a criterion } \\
\text { for sustainable transportation by OECD } \\
\text { (2002) and under pollution rules by CPCB } \\
\text { (2011). }\end{array}$ & $\begin{array}{l}\text { Bologna (2000), Italy (OECD, } \\
\text { 2000b), WBCSD (Eads, 2001), OECD } \\
\text { (2002), Lyons (Nicolas et al., 2003) }\end{array}$ \\
\hline EA14 & $\begin{array}{l}\% \text { of road having plantation on both } \\
\text { side }\end{array}$ & $\begin{array}{l}\text { This indicates the extent of roadside } \\
\text { plantation in the city as a policy. }\end{array}$ & \\
\hline EA15 & $\begin{array}{l}\text { Vehicle scrap formation per year } \\
\text { (ton/yr) }\end{array}$ & $\begin{array}{l}\text { This indicates the volume of waste } \\
\text { produced by transportation system. }\end{array}$ & USEPA(1996) \\
\hline EA16 & \% Vehicle scrap recycled & $\begin{array}{l}\text { This indicator signifies the level of recycling } \\
\text { of vehicle scraps. A higher the value of } \\
\text { indicator indicated improved situation. }\end{array}$ & $\begin{array}{l}\text { WBCSD (Eads, 2001), Nova Scotia } \\
\text { (GPI, 2006), New Zealand (2011) }\end{array}$ \\
\hline EA17 & $\begin{array}{l}\text { No. of unresolved environmental } \\
\text { cases pending in court road and rail } \\
\text { transport }\end{array}$ & $\begin{array}{l}\text { This is an indicator of environmental } \\
\text { regulation conflicts related to transportation } \\
\text { in the city. Higher value of the indicator } \\
\text { shows more regulations and less } \\
\text { compliance. }\end{array}$ & \\
\hline
\end{tabular}




\section{Concluding Remarks and the Road Ahead}

This paper uses the MVBB conceptual framework for sustainable development applies the same in transportation domain of Mumbai city as case study. The systematic review of literature on sustainable transportation indicator initiatives worldwide has led to development of a set of potential indicators for assessing sustainability of transportation system of city of Mumbai. Following the MVBB framework, these 54 potential indicators are classified into three dimensions of urban sustainability-economic efficiency (19 indicators), social wellbeing (18 indicators) and ecological acceptability (17 indicators).

Indicators are a must for sustainability study. Indicators are not cure by themselves. Nevertheless they provide clues to the cause of the disease and gives direction for treatment. The next step in the research is to filter this set of potential indicators to arrive at the final list. The indicators featuring in the final list can be monitored to prepare sustainability report card for the transportation sector of Mumbai. Indicators help policy preparation. The transportation policy of the city can be revisited in the backdrop of these indicators.

\section{References}

Ahmed, Q. I., Huapu, L., and Shi, Y. (2008) "Urban transportation and equity: A case study of Beijing and Karachi” Transportation Research Part A: Policy and Practice, Vol. 42, No. 1, pp. 125-139.

Åkerman, J. and Höjer, M. (2006) "How much transport can the climate stand?- Sweden on a sustainable path in 2050”, Energy Policy, Vol. 34, No. 14, pp.1944-1957.

Australia (1998) "Environmental Indicators for National State of Environment reporting - human settlements", Department of Environment, Australia.

Banister, D. (1999) “Planning more to travel less: Land use and transportation” Town Planning Review, Vol. 70, No. 3, pp. 313-338.

Baum, H. and Kurte, J. (2002) "Transport and Economic Development", Report of the Hundred and Ninth Round Table on Transport Economics held in Paris on 29-30 March 2001, European Conference of Ministers of Transport, 2002, pp. 5-49.

Binswanger, P. B., Kandker, S.R, and Rosenzweig, M. R. (1993) "How infrastructure and financial institutions affect agricultural output and investment in India," Journal of Development Economics, Vol. 41, No. 2, pp. 337-366.

Black, J.A., Paez, A., and Suthanaya, P.A. (2002) "Sustainable urban transportation: performance indicators and some analytical approaches”, Journal of the Urban Planning and Development, Vol. 128, No. 4, pp. 184209.

Black, W. R. (1996) "Sustainable transportation: a US perspective”, Journal of Transport Geography, Vol. 4, No. 3, pp. 151-159.

Black, W.R. and Nijkamp, P. (Eds.) (2002). Social Change and Sustainable Transport., Bloomington: Indiana University Press.

Bologna (2000) "The State of The Environment Report of the City of Bologna”, Annex C of 'Transport/Environment Indicators: The experience of Italy' In: Towards a sustainable development Indicators to measure progress, Rome Conference, OECD, Paris. 
Cape Town (2006) “Integrated Transport Plan for the City of Cape Town: 2006 to 2011”, Annexure B, City of Cape Town. Available at: http://www.capetown.gov.za/en/IDP/Documents/Statutory\%20compliance\%20plans/M.Integrated\%20Tran sport\%20Plan.pdf (last accessed on March 22, 2011).

CPCB (Central Pollution Control Board) (2009) "National ambient air quality standards”, The Gazette of India, Part III, Section 4, Govt of India, New Delhi.

CPCB (Central Pollution Control Board) (2010) "Status of Vehicular Pollution Control Programme in India”, PROBES/136/2010, CPCB, Govt of India, New Delhi, March.

CPCB (Central Pollution Control Board) (2011) 'The noise pollution (regulation and control) rules, 2000', Govt of India, New Delhi. Available at: http://cpcb.nic.in/divisionsofheadoffice/pci2/noise_rules_2000.pdf (last accessed on March 10, 2011).

CST (Center for Sustainable Transport) (2002) "Sustainable Transport Performance Indicators (STPI) - A Synopsys Report”, CST. Available at: http://cst.uwinnipeg.ca/documents/STPI_synopsis.pdf (last accessed on March 20, 2011).

CSTI (Center for Sustainable Transport India) (2007), “12 Indian Cities: Transport Indicators”, EMBARQ (The WRI centre for Sustainable Transport). CSTI, Available at: http://www.embarq.org/sites/default/files/IndiaTransport-Indicators.pdf (last accessed on March 20, 2011).

Dahl, P. C. (1994) “A survey of oil product demand elasticities for developing countries”, OPEC Review, Vol. 18, No. 1, pp. 47-86.

Dhakal, S. (2002) "Report on Indicator related research for Kitakyushu Initiative”, Ministry of Environment, Japan.

Donatiello, G. (2001) “Environmental sustainability indicators in urban areas: An Italian experience”, Working Paper 16 (Paper submitted by the National Statistical Institute of Italy), Statistical Commission and Economic Commission for Europe (ECE), Joint ECE/Eurostat Work Session on Methodological Issues of Environment Statistics, Ottawa, Canada, 1-4 October.

Duleep, K.G. (1997) “Keep on truckin’-sustainably?” In: DeCicco, J., Delucchi, M. (Eds.) Transportation, Energy, and Environment: How Far Can Technology Take Us? American Council for an Energy-Efficient Economy, Washington, D.C., pp. 179-194.

Eads G.C. (2001) “Indicators of Sustainable Mobility”, World Business Council for Sustainable Development (WBCSD), Switzerland.

EC (European Communities) (2001) “Towards a local sustainability profile”, 'European Common Indicators: Methodology Sheets', Official publications of the European Communities, May.

EEA (European Environment Agency) (2010) “Towards a resource-efficient transport system”, TERM 2009: indicators tracking transport and environment in the European Union, No. 2/2010, EEA Report, EEA, Copenhagen.

Faiz, A., and Sturm, P. J. (2002) “New directions: air pollution and traffic in developing countries”, In: Austin, J., Brimblecombe P., and Sturges, W. (Eds.) Air Pollution Science for the 21st Century, Elsevier Press.

Gakenheimer, R. (1999), “Urban mobility in the developing world”, Transportation Research Part A: Policy and Practice, Vol. 33, No. 7-8, pp. 671-689.

Global Urban Observatory (2003) "Slums of the World: The face of urban poverty in the new millennium?", Working Paper, United Nations Human Settlements Programme, UN-Habitat, Nairobi, Kenya.

Gordon, D. (1995) “Sustainable transportation: What do we mean and how do we get there?”, In: Shaheen, S., Sperling, D. (Eds.) Transportation and Energy: Strategies for a Sustainable Transportation System, American Council for an Energy-Efficient Economy, Washington, D.C., pp. 1-11.

Greene, D. L., and Wegener, M. (1997) “'Sustainable transport”, Journal of Transportation Geography, Vol. 5, No. 3, pp. 177-190.

GTZ (Deutsche Gesellschaft fur Technische Zusammenarbeit) (2002) "Urban Transport and Poverty in Developing Countries: Analysis and Options for Transport Policy and Planning,” Berlin: GTZ.

Gwilliam, K. (2003) “Urban transport in developing countries”, Transport Reviews, Vol. 23, No. 2, pp. 197216.

Hall, P. A. and Pfeiffer, U. (2000) Urban Future 21: a Global Agenda for Twenty-First Century Cities, London: Spon, p.21. 
Hensher, D. A. (2008) "Climate change, enhanced greenhouse gas emissions and passenger transport - What can we do to make a difference?”, Transportation Research Part D: Transport and Environment, Vol. 13, No. 2, pp. 95-111.

Holden, E., and Norland, I. T. (2005) “Three challenges for the compact city as a sustainable urban form: Household consumption of energy and transport in eight residential areas in the Greater Oslo Region”. Urban Studies, Vol. 42, No. 12, pp. 2145-2166.

Hualin, Z. (2001), ”Urban Environmental Management in China”, Department of Pollution Control, SEPA. Available at: http://www.docstoc.com/docs/34641590/Urban-Environmental-Management-in-China. (last accessed on March 12, 2011).

IEA (International Energy Agency) (2007a) $\mathrm{CO}_{2}$ Emissions from Fuel Combustion: 1971-2005, 2007 Edition, Paris: IEA.

IEA (International Energy Agency) (2007b) World energy outlook 2007: China and India Insights, Paris: IEA.

IEA (International Energy Agency) (2008) World energy outlook 2008, Paris: IEA.

Jacoby, H. G. (1998) 'Access to Markets and the Benefits of Rural Roads: A Nonparametric Approach', Working Paper 2275, World Bank, Washington D.C., June.

Jeon, C. M. and Amekudzi, A. A. (2005) “Addressing sustainability in transportation systems: definitions, indicators, and metrics”, ASCE Journal of Infrastructure Systems, Vol. 11, No. 1, pp. 31-50.

Jeon, C. M., Amekudzi, A. A., and Guensler, R. (2007) "Evaluating transportation system sustainability: Atlanta metropolitan region” In: Proceedings of the 2007 Annual Meeting of the Transportation Research Board CDROM, January 2007, Washington, D.C.

Kenyon, S., Lyons, G., and Rafferty, J. (2002) “Transport and social exclusion: investigating the possibility of promoting inclusion through virtual mobility”. Journal of Transportation Geography, Vol. 10, No. 3, pp. 207-219.

Krichene, N. (2002) “World crude oil and natural gas: a demand and supply model” Energy Economics, Vol. 24, No. 6, pp. 557-576.

Laquian, A. A. (2004) "Who are the poor and how are they being served in Asian cities?”, Paper presented at the 'Forum on Urban Infrastructure and Public Service Delivery for the Urban Poor, Regional Focus: Asia,' sponsored by the Woodrow Wilson International Center for Scholars and the National Institute of Urban Affairs, India Habitat Centre, New Delhi.

Lindquist, E. (1998) "Moving Toward Sustainability: Transforming a Comprehensive Land Use and Transportation Plan”. In: Transportation Research Record 1617, Transportation Research Board, National Research Council, Washington, D.C., pp. 1-9.

Litman, T. (2011) Well Measured: Developing indicators for sustainable and livable transport planning. Victoria Transport Policy Institute, January. Available at: http://www.vtpi.org/wellmeas.pdf (last accessed on March 20, 2011).

London (2004) 2004 report on London's Quality of Life Indicator, London Sustainable Development Commission, Greater London Authority, April.

Loo, B. P. Y. (2002) "Role of Stated Preference Methods in Planning for Sustainable Urban Transportation: State of Practice and Future Prospects”, Journal of Urban Planning and Development, Vol. 128, No. 4, pp. 210-224.

Loo, B. P. Y. and Chow, S. Y. (2006), "Sustainable Urban Transportation: Concepts, Policies, and Methodologies”, Journal of Urban Planning and Development, Vol. 132, No. 2, pp. 76-79.

May, A.D., Jopson, A. F. and Matthews. B. (2003) "Research challenges in urban transport policy”, Transport Policy, Vol. 10, No. 3, pp. 157-164.

MCGM (Municipal Corporation of Greater Mumbai) (1998-2009) Environment Status of Brihanmumbai (Greater Mumbai), Air Quality Monitoring and Research Laboratory, Khar, Mumbai.

MCGM (Municipal Corporation of Greater Mumbai) (2010) Mumbai Human Development Report 2009, MCGM. Oxford University Press, New Delhi.

MMRDA (Mumbai Metropolitan Region Development Authority) (2009) Annual issues of Basic Trasport \& Communication Statistics for Mumbai Metropolitan Region, MMRDA office, Mumbai. 
Murray, C.J.L., Lopez, A.D. (1996), eds. The global burden of disease: a comprehensive assessment of mortality and disability from diseases, injuries, and risk factors in 1990 and projected to 2020. Boston, MA, Harvard School of Public Health.

Nathan, H. S. K. and Reddy, B. S. (2011a) "Towards a conceptual framework for development of sustainable development indicators for an urban setup”, International Journal of Sustainable Development, Forthcoming. Available at: http://www.inderscience.com/browse/index.php?journalID=25\&action=coming.

Nathan, H. S. K. and Reddy, B. S. (2011b) “Criteria Selection for Sustainable Development Indicators", International Journal of Multicriteria Decision Making. Vol. 1, No. 3, pp 257279.

New Zealand (2011) “All transport monitoring indicators', Ministry of transport, New Zealand. Available at: http://www.transport.govt.nz/ourwork/tmif/allindicatorsbynumber/ (last accessed on March 11, 2011)

Newman, P., Birrell, R., Holmes, D., Mathers, C., Newton, P., Oakley, G., O’Connor, A., Walker, B., Spessa, A. and Tait, D. (1996) Human settlements in Australia: State of the Environment 1996, Department of Environment Sport and Territories, Melbourne: CSIRO Publishing.

Nicolas, J. P, Pochet, P., and Poimboeuf, H (2003) "Towards sustainable mobility indicators: application to the Lyons conurbation”, Transportation Policy, Vol. 10, No. 3, pp. 197-208.

Genuine Progress Index (GPI) (2006) “The GPI transportation accounts: Sustainable transportation in Nova Scotia”, Measuring Sustainable Development, GPI Atlantic, Canada, November.

OECD (Organization of Economic Co-operation and Development) (2000a), "Transport/ Environment Indicators: The experience of Finland” In: Towards a sustainable development - Indicators to measure progress, Rome Conference, OECD, Paris.

OECD (Organization of Economic Co-operation and Development) (2000b) "Transport/ Environment Indicators: The experience of Italy”, In: Towards a sustainable development - Indicators to measure progress, Rome Conference, OECD, Paris.

OECD (Organization of Economic Co-operation and Development) (2000c) "Transport/ Environment Indicators: OECD Overview”, In: Towards a sustainable development - Indicators to measure progress, Rome Conference, OECD, Paris.

OECD (Organization of Economic Co-operation and Development) (2002), OECD Guidelines towards environmentally sustainable transport, OECD, Paris.

OECD (Organization of Economic Co-operation and Development) (2003) “OECD Environmental Indicators: Development, Measurement and Use”, Reference paper, Environmental Performance and Information Division, OECD, Paris.

O’Rourke, L. and Lawrence, M. F. (1995) "Strategies for goods movement in a sustainable transportation system”, In: Shaheen, S. and Sperling, D. (Eds.) Transportation and Energy: Strategies for a Sustainable Transportation System, American Council for an Energy-Efficient Economy, Washington D.C., pp. 59-76.

Poudenx, P. (2008) "The effect of transportation policies on energy consumption and greenhouse gas emission from urban passenger transportation”, Transportation Research Part A: Policy and Practice, Vol. 42, No. 6, pp. 901-909.

Price, L., Michaelis, L., Worrell, E., and Khrushch, M. (1998) "Sectoral Trends and Driving forces of global energy use and greenhouse gas emissions”, Mitigation and Adaptation Strategies for Global Change, Vol. 3, No. 2-4, pp. 263-319.

Pucher J., Korattyswaropam, N., Mittal, N., and Ittyerah, N. (2005) “Urban transport crisis in India”, Transport Policy, Vol. 12, No. 3, pp. 185-198.

Ramani, T., Zietsman, J., Eisele, W., Rosa, D., Spillane, D., and B. Bochner (2009) "Developing Sustainable Transportation Performance Measures for TxDOT's Strategic Plan: Technical Report”, Texas Transportation Institute, College Station, TX.

Richardson, B. C. (1999) "Role of the Motor-Vehicle Industry in a Sustainable Transportation System", Transportation Research Record, No. 1702, pp. 21-27.

Richardson, B. C. (2000) “Toward a policy on a sustainable transportation system”, Transportation Research Record, No. 1670, pp. 27-34.

Richardson, B. C. (2005) "Sustainable transport: analysis frameworks”, Journal of Transport Geography, Vol. 13 , No. 1, pp. 29-39. 
Sa'́nchez, T. W., Stolz, R., and Ma, J. S. (2003) "Moving to Equity: Addressing Inequitable Effects of Transportation Policies on Minorities”, The Civil Rights Project at Harvard University, Cambridge, MA.

Schiller, P. L., Brunn, E. C. and Kenworthy, J. R. (2010) An introduction to sustainable transportation: policy, planning and implementation, London: Earthscan.

Schipper, L., (2003) “Sustainable urban transport in the 21st century: a new agenda”, In: Proceedings of Conference: Transportation, Energy, and Environmental Policy: Managing Transitions, held in Monterey, CA, 9/11/2001-9/12/01. Transportation Research Board (TRB), Washington, D.C.

Sustainable Seattle (2004) "Indicators of Sustainable Community-A status report on long-term cultural, economic, and environmental health for Seattle/King County”, Washington, March.

TAC (Transportation Association of Canada) (1999) “Urban transportation indicators”, TAC, Ottawa.

Transportation Research Board (1997) Toward a sustainable future, addressing the long-term effects of motor vehicle transportation on climate and ecology, Special Report 251, Washington, D.C.: National Academy Press.

UK (United Kingdom) (2006) Sustainable Development indicators in your pocket: 2006, Department for Environment, Food, and Rural Affairs (DEFRA), UK.

UNCHS (United Nations Center for Human Settlement) (2004) Urban Indicator Guidelines: Monitoring the Habitat Agenda and Millennium Development Goal, UNCHS, UN Habitat, Nairobi, August.

UNCSD (United Nations Commission for Sustainable Development) (1996) "Indicators of Sustainable Development Framework and Methodologies", Background Paper 3, Division for Sustainable Development, United Nations, New York.

UNFPA (United Nations Fund for Population Division) (1999), State of World Population: six billion, a time for choice, United Nations Population Fund, New York.

USEPA (United States Environmental Protection Agency) (1996) "Indicators of the Environmental Impacts of Transportation: Highway, Rail, Aviation, and Maritime Transport”, EPA- 230-R-96-009, USEPA, October.

USDOT (United States Department of Transportation) (2003) “DOT Performance Plan- FY2004”, DOT, Govt. of USA, February.

Vasconcellos, E. (2001) Urban Transport, Environment and Equity: The Case for Developing Countries. London: Earthscan.

WBCSD (World Business Council for Sustainable Development) (2004) Mobility 2030: Meeting the challenges to sustainability - The Sustainable Mobility Project - Full report 2004, WBCSD, Switzerland.

WCED (World Commission on Environment and Development) (1987) 'Our Common Future: The Brundtland report', WCED, UN, Oxford University Press.

WHO (World Health Organization) (2000) Transport, Environment and Health, WHO Regional Publications, European Series, 89 and Violence Prevention, WHO.

WHO (World Health Organization) (2002) The Injury Chart Book, Department of Injuries and Violence Prevention, WHO, Geneva.

World Bank (1996) Sustainable Transport: Priorities for Policy Reform. The International Bank for Reconstruction and Development/The World Bank, Washington, D.C.

World Bank (2002) “India’s Transport Sector: The Challenged ahead”, Volume II, Background Papers, Energy and Infrastructure Sector Unit, South Asia Region, The World Bank, May.

World Gazetteer (2011) "World: largest cities and towns and statistics of their population (2010)”, World Gazetteer. Available at: http://world-gazetteer.com (last accessed March 15, 2010).

Zietsman, J. (2000) "Incorporating Sustainability Performance Measures Into the Transportation Planning Process”, Ph.D. Dissertation, Texas A\&M University, College Station, Texas, December.

Zietsman, J. and Rilett, L. R. (2001) “Sustainable transportation: fad or fabulous”, Paper presented to the 20th Annual South African Transport Conference, South Africa, 16-20 July. Available at: http://www.up.ac.za/dspace/bitstream/2263/8046/1/2b5.pdf (last accessed on March 10, 2011) 